\title{
Endometriosis-Associated Ovarian Cancer: The Origin and Targeted Therapy
}

\author{
Kosuke Murakami ${ }^{\circledR}$, Yasushi Kotani, Hidekatsu Nakai and Noriomi Matsumura * \\ Department of Obstetrics and Gynecology, Kindai University Faculty of Medicine, Osakasayama, \\ Osaka 589-8511, Japan; kmurakami@med.kindai.ac.jp (K.M.); y-kotani@med.kindai.ac.jp (Y.K.); \\ nakai@med.kindai.ac.jp (H.N.) \\ * Correspondence: noriomi@med.kindai.ac.jp; Tel.: +81-72-366-0221
}

Received: 22 May 2020; Accepted: 22 June 2020; Published: 24 June 2020 updates

\begin{abstract}
Endometrial cysts (ECs) are thought to be the origin of endometriosis-associated ovarian cancer (EAOC). A hypothesis that the oxidative stress of iron in cysts causes "malignant transformation of ECs" has been proposed, but this has not been verified. Several population-based studies showed that endometriosis was a risk factor but did not reflect the "malignant transformation of ECs". A review showed that most patients were diagnosed with EAOC early in monitoring following detection of ECs, and that these cases might have been cancer from the start. Epidemiologically, EAOC was reduced by hysterectomy rather than by cystectomy of ECs. Gene mutation analyses identified oncogenic mutations in endometriosis and normal endometrium and revealed that the same mutations were present at different endometriotic lesions. It was also shown that most of the gene mutations found in endometriosis occurred in normal endometrium. Taking together, EAOC might be caused by eutopic endometrial glandular epithelial cells with oncogenic mutations that have undergone menstrual blood reflux and engrafted in the ovary, rather than by low-risk ECs acquiring oncogenic mutations and becoming malignant. This review discusses the mechanisms of EAOC development and targeted therapy based on genetic variation in EAOC with a focus on eutopic endometrium.
\end{abstract}

Keywords: chocolate cyst; clear cell carcinoma; endometrial cyst; endometrioid carcinoma; endometriosis; endometriosis-associated ovarian cancer; malignant transformation

\section{Introduction}

Endometriosis is a disease in which the endometrium or similar tissue develops outside the original uterine cavity [1]. Endometriosis is a risk factor for ovarian cancer [2], and in a recent meta-analysis, the odds ratio for ovarian cancer in the presence of endometriosis was 1.42 [3]. Endometriosis-associated ovarian cancer (EAOC) is thought to develop from ovarian endometrial cysts (ECs) [4]. EAOC is mainly endometrioid or clear cell carcinoma. Ovarian endometrioid carcinoma (OEC) is the most common type of EAOC, occurring in approximately $75 \%$ of cases [5]. In Japan, however, ovarian clear cell carcinoma (OCCC), which is refractory to chemotherapy and has a poor prognosis, is more prevalent, accounting for approximately a quarter of all epithelial ovarian cancers [6].

Regarding the management of endometriosis, the European Society of Human Reproduction and Embryology (ESHRE) guidelines recommend that even if endometriosis increases the risk of developing ovarian cancer, there is no way to reduce it, and therefore its management should not be changed with concern for the ovarian cancer [7]. However, the Japanese guidelines still emphasize the risk of the malignant transformation of ECs, and the concept of "prevention of malignant transformation" is presented. Especially in patients over 40 years of age, oophorectomy for the purpose of histological retrieval is considered [8]. Therefore, the treatment of ECs is controversial when symptoms are negligible without treatment or when symptoms are under control with medication. 
In this review, we discuss the mechanisms of EAOC development and targeted therapy according to genetic variations in EAOC based on the evidence to date, with a focus on eutopic endometrium.

\section{Endometriosis and EAOC}

Endometriosis is thought to involve the reflux of menstrual blood into the abdominal cavity [4]. Increased frequency of menstruation makes endometriosis more likely to arise [9]. As a result, it has been reported to occur in approximately $10 \%$ of women of reproductive age in modern society, where the prevalence of late births is increasing [10]. The main symptoms of endometriosis are dysmenorrhea and infertility [1]. Other symptoms in patients with endometriosis include lower back pain, lower abdominal pain, defecation pain, and sexual intercourse pain, even if they are not menstruating. These symptoms are more common in women in their $20 \mathrm{~s}$ and $30 \mathrm{~s}$ and abate with a decrease in estrogen as they age [10]. Treatment of endometriosis is mainly medication or surgery and is selected based on the type and severity of the symptoms, as well as the patient's age and wishes for pregnancy. Medications are effective for pain, and when analgesics, such as non-steroidal anti-inflammatory drugs (NSAIDs), are ineffective, oral contraceptives (OCs) or progestin may be used to relieve symptoms by suppressing the secretion of estrogen or acting directly on the lesion [7]. Gonadotropin-releasing hormone agonists and antagonists may also be used when patients fail to respond to OCs or progestin $[7,11]$. Thus, with the recent developments in therapies, surgery can often be avoided in many cases of ECs [12]. However, a major problem is that ovarian cancer can develop during follow-up of tumors that are considered as ECs.

There have been many reports of oxidative stress in the microenvironment of endometriosis [13]. Oxidative stress in endometriosis is thought to cause infertility and carcinogenesis [4,14]. Yamaguchi et al. reported that fluid in ECs contains abundant iron, which causes oxidative stress; 5-fold diluted fluid from ECs caused DNA damage in Chinese hamster lung fibroblast V79 cells [15]. Excess iron generates reactive oxygen species (ROS) through the Fenton reaction $\left(\mathrm{Fe}^{2+}+\mathrm{H}_{2} \mathrm{O}_{2} \rightarrow \mathrm{Fe}^{3+}+\mathrm{OH}^{-}+\bullet \mathrm{OH}\right)$ [16]. ROS causes not only gene mutations but also epigenetic alterations, such as DNA methylation [17]. Kobayashi et al. proposed a hypothesis suggesting that at least two steps are necessary for ECs to develop into EAOC [18]. In the first step, DNA damage, mutations, and genomic instability might be caused via the Fenton reaction. High levels of ROS might be cytotoxic and cause apoptosis, and thus may not promote carcinogenesis. In the second step, when cells with high antioxidant capacity arise, selection of these cells might occur, resulting in their proliferation to cause carcinogenesis. However, there has been no data on whether EAOC has a strong ability to resist oxidative stress, and there is no evidence to support this hypothesis. In addition, it has recently been reported that the interaction between oxidative stress and non-coding microRNAs has an important role in the development of EAOC [19], but further study is required.

\section{Clinical Epidemiology}

\subsection{How Long Does It Take for ECs to Become EAOC?}

Women with endometriosis are more likely to develop EAOC in their late 40s, but after menopause, the incidence of ovarian cancer is not increased [20,21]. The risk ratio of ovarian cancer after menopause is 0.8 in women with previously diagnosed endometriosis [22]. There is no evidence that EAOC is more likely to develop in older women or that carcinogenesis is increased if ECs are followed up after menopause. These data contradict the hypothesis that prolonged exposure to the contents of ECs leads to DNA damage and increases carcinogenesis. Therefore, this hypothesis is not supported by the epidemiological data. 
In Japan, a prospective cohort study of carcinogenesis during follow-up of ECs was performed [23]. This study enrolled 6398 cases of EC at an average age of 38.4 from 1985 to 1995 and followed up for an average of 12.8 years. As a result, ovarian cancer was diagnosed in 46 cases ( $0.7 \%)$. In this study, the risk ratio was adjusted for age at the time of diagnosis and compared with healthy women. Women with ECs were nine times more likely to have ovarian cancer than healthy women. The histological types were mostly clear cell carcinoma and endometrioid carcinoma. Although it was published 12 years ago, it is still the only report to examine the risk of carcinogenesis when following up cysts diagnosed as ECs. However, these results must be interpreted with care. Firstly, the small sample size requires caution in interpretation regarding the frequency of $0.7 \%$ and the figure of 9 times compared to the control. Secondly, the study was begun more than 35 years ago when transvaginal ultrasound and MRI were uncommon, and hence the diagnostic accuracy might not reflect the present diagnostic capabilities. Thirdly, this study did not distinguish between carcinogenesis from the observed ECs and that derived elsewhere. Hence, this study examined "the risk of women who had been diagnosed with ECs being subsequently diagnosed with ovarian cancer", rather than "malignant transformation of ECs".

We reviewed case reports of ovarian cancer originating from ECs that have been published since 2000 because these cases were likely to be well observed by transvaginal ultrasound or MRI [24]. In total, 79 cases in 32 articles were collected, and the histological types were mostly clear cell carcinoma and endometrioid carcinoma. The authors were all Japanese except for two papers (two cases). The cumulative carcinogenesis rate was $50 \%$ at 3 years and $75 \%$ at 5 years. Except for one case in the 13th year, all cases were diagnosed with cancer within 10 years. The number of cases of carcinogenesis was highest in the first year after the start of follow-up and tended to decrease over time. These results were very surprising, as it was expected that there would be a publication bias towards cases that developed cancer after long-term follow-up. Adenocarcinoma takes more than five years to reach a detectable size after cancer cells develop [25]. In other words, it was considered that almost all reported cases of "malignant transformation of ECs" might be "cancer from the beginning".

\subsection{Probability of Ovarian Cancer Being Diagnosed in Surgical Specimens of Endometrial Cysts}

When surgery is performed on patients with a diagnosis of ECs, ovarian cancer may be identified pathologically. In Taiwan, a retrospective single-center study found that 7629 surgeries were performed following preoperative diagnosis of ECs and $0.14 \%$ (11 cases) were diagnosed with ovarian cancer postoperatively [26]. If such cases were followed without surgery, ovarian cancer might have developed within a few years.

In another study, among patients diagnosed with endometriosis in the Taiwan National Health Insurance Research Database who underwent surgery from 2000 to 2010, ovarian cancer occurred in 39/5945 cases in the endometriosis group and 36/23,780 cases in the control group [27]. The hazard ratio (HR) of ovarian cancer with endometriosis was 5.6 and that of developing OCCC was 7.4. However, the actual cumulative curve for carcinogenesis demonstrated that $0.4 \%$ of cases had been diagnosed with ovarian cancer within a month of being registered as endometriosis (Figure 1). That is, it was considered that the "endometriosis group" included $0.4 \%$ (24 cases) of "ovarian cancer". If these cases had been followed up without surgery, many would have been diagnosed with cancer within a few years. Except for the first month after enrollment, 12 cases of ovarian cancer occurred after surgery for endometriosis, but the risk was approximately $2-3$ times higher than that of the controls. This is greater than the data of the population-based study, which is going to be discussed below, but might be because the median age of the cohort was around 40 years and the analysis was limited to the age at which the risk ratio of ovarian cancer was greatest with endometriosis. 
One month
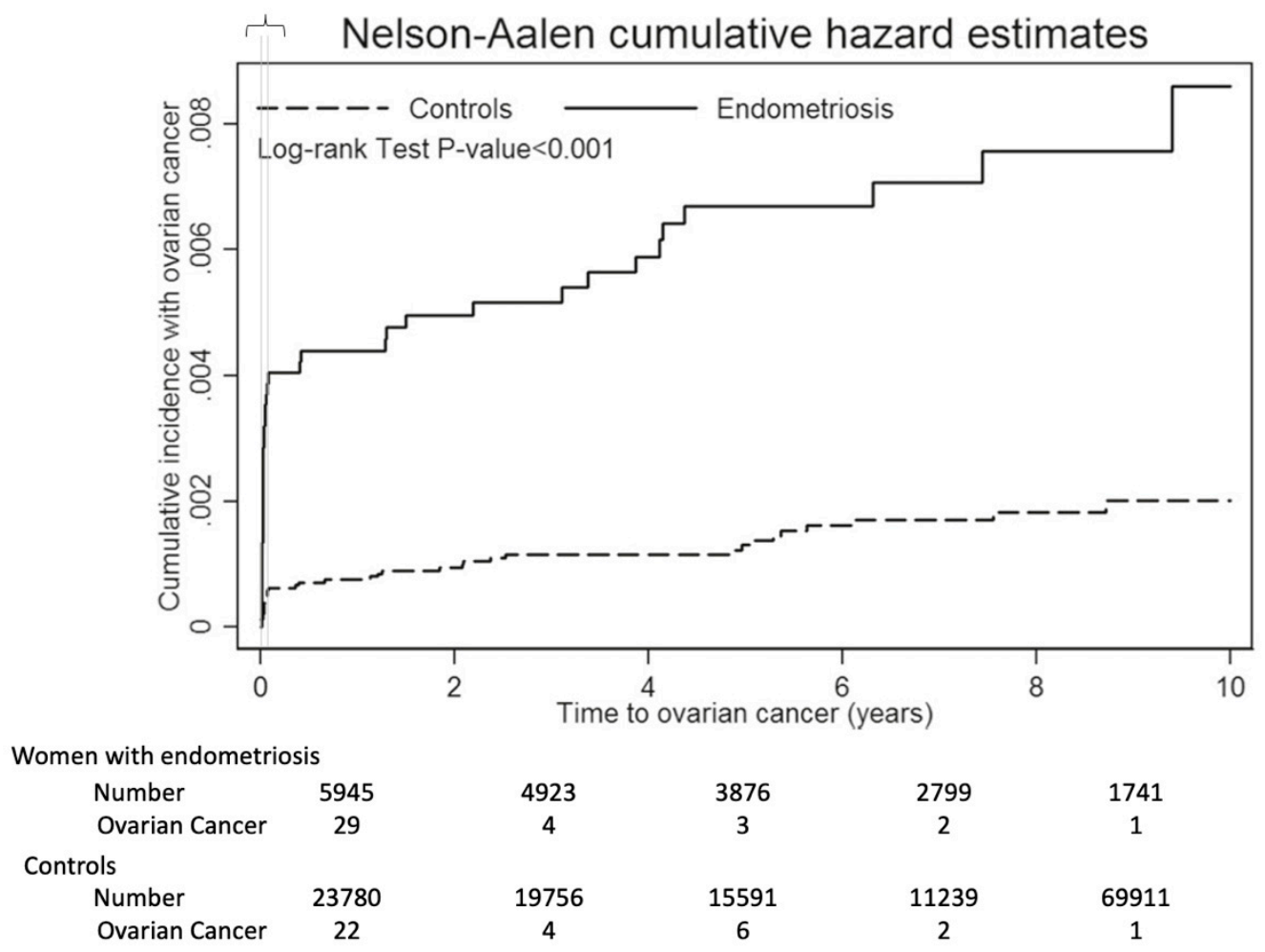

Figure 1. The actual cumulative curve for carcinogenesis from endometrial cysts. Graph showing that in 5945 women enrolled as endometriosis, 24 (0.4\%) ovarian cancers developed within 30 days of enrollment. This figure was made by modifying a figure from BMC Cancer 2014 [27].

\subsection{Large-Scale Population-Based Studies}

Among 13 case-control studies, the relationship between endometriosis and the risk of developing ovarian cancer was investigated in 7911 ovarian cancers and 13,226 controls [28]. Twelve of the 13 studies were population based, with the earliest case collection beginning in 1992. When there had been a history of endometriosis, the risk of ovarian cancer was 1.49 times greater, with the risk of OCCC and OEC significantly higher at 3.73 times greater and 2.32 times greater, respectively. Low-grade serous carcinoma, unrelated to endometriosis, also increased by 2.02 times. Seromucinous borderline tumor, which is similar to serous borderline tumor and low-grade serous carcinoma at low magnification, is known to be strongly associated with endometriosis, but this pathological concept was clearly presented in 2002 [29]. Thus, a certain number of tumors that are now classified as seromucinous borderline tumor might have been classified as low-grade serous carcinoma in the above case-control studies. In a meta-analysis of 22 large population-based cohorts of 1.3 million women, 5584 cases of ovarian cancer were diagnosed and were examined for risk factors [30]. The risk of ovarian cancer was shown to increase by 1.35 times if previously diagnosed with endometriosis. The risk increased by 2.87 times in OCCC and by 2.32 times in OEC. The reason for the lower risk ratio in this study might be that 17 of 22 cohorts had a median age of 50 years or older. The method of the large-scale population-based study as described above showed that a history of endometriosis was a risk factor, rather than "malignant transformation of ECs". In such population-based studies, "cancer from the beginning" is less likely to be included.

A meta-analysis was conducted on the risk of developing ovarian cancer in women with endometriosis [31]. However, this contained various methods of research and was difficult to interpret. 


\subsection{Surgery and Medication for Endometriosis and Risk of Ovarian Cancer}

To determine the origin of cancer, it is useful to identify precancerous lesions by histopathology. The histology of ECs often shows a simple monolayer of epithelium, with few abnormal mitotic cells or stratification. In many cases, this monolayer of epithelium and endometrial glandular epithelial cells are hardly found [32]. That is, most EC cases do not have precancerous lesions. It has been reported that "atypical endometriosis", which is assumed to be a precancerous lesion, was found in $60 \%$ of cases of endometriosis with ovarian cancer but in only $2 \%$ of cases without ovarian cancer [33]. However, the interpretation of these data requires caution, as there are very few reports on atypical endometriosis and its definition has not been determined. Nuclear atypia with no proliferative features, which are often seen, is considered to be a reactive change. A proliferative lesion similar to a precancerous lesion of endometrioid carcinoma of the endometrium is considered to be a true precancerous lesion, but this is rarely observed [34].

The relationship between the type of surgery and the risk of developing ovarian cancer is also important. Fallopian tubal ligation reduces serous carcinoma by only about $20 \%$ but OCCC and OEC by about $50 \%$. The effect is observed early (2-9 years) after tubal ligation and continues thereafter $[35,36]$.

If ECs are the origin of ovarian cancer, cystectomy should be able to prevent ovarian cancer. However, it was reported that ovarian cancer sometimes occurs in the ipsilateral ovary following cystectomy $[37,38]$. The risk ratio of developing ovarian cancer after surgery (most likely cystectomy or oophorectomy) for endometriosis compared with controls was 1.69 in Denmark (3.37 for OEC and 3.03 for OCCC) [39], 1.77 in Scotland [40], and 1.60 in Canada [21]. That is, in such surgery, the risk of developing ovarian cancer did not decrease as compared with the population-based data described above. However, according to a report from Sweden, in women hospitalized for a diagnosis of endometriosis, the risk ratio of ovarian cancer was 1.54 without hysterectomy and 1.05 with hysterectomy, with hysterectomy eliminating the risk of ovarian cancer [20]. In addition, in a study reported in 2019 that followed 830,000 women for 27 years, hysterectomy without oophorectomy reduced the risk of ovarian cancer to HR 0.17 in women with endometriosis [41]. Thus, the risk of developing EAOC was reduced with hysterectomy rather than cystectomy of ECs. Furthermore, as described above, there was no increase in the incidence of ovarian cancer after menopause related to a history of endometriosis. These results suggest that the reflux of eutopic endometrial glandular epithelial cells through the fallopian tube might be involved in the development of EAOC, and not through the endometriotic lesions gradually turning into cancer. When using OCs for more than 10 years, the risk ratio for ovarian cancer was 0.21 with endometriosis and 0.47 without endometriosis [42]. Therefore, a reduction in menstrual blood and suppression of ovulation by OCs might also contribute to the prevention of EAOC.

\section{Genetic Analysis of Endometrium, Endometriosis, and EAOC}

It has been suggested that EAOC arises from endometriosis because EAOC exhibits mutations in ARID1A, PIK3CA, and PTEN as well as loss of heterozygosity at a high frequency, which is also common in coexisting endometriosis [43-46]. Recently, however, more detailed genetic mutation analyses of endometriosis using next-generation sequencing (NGS) are changing the conventional concept. In reports examining deep endometriosis, which is not usually associated with carcinogenesis, 19 of 24 patients had gene mutations and 5 had oncogenic mutations. Endometriotic lesions in these cases, such as in the Douglas pouch, rectal surface, and peritoneum of the vesicouterine pouch, carried the same gene mutation [47]. In other words, it was presumed that the origin of these gene mutations was eutopic endometrium. In a study of 107 cases of EC and 82 cases of normal endometrium, Suda et al. reported numerous KRAS and PIK3CA mutations in both endometriosis and normal endometrial glandular epithelium, and the same mutations were observed even at different sites of endometriosis [48]. Similarly, it has been reported that many of the genetic mutations found in endometriosis can also be found in eutopic normal endometrium by exome sequencing [49]. In mouse models of ARID1A and PIK3CA mutations in the endometrium, it was reported that 
endometriosis occurred when the endometrial glands were easily regurgitated into the peritoneal cavity by salpingectomy [50]. It has also been reported that eutopic endometrium has numerous genetic mutations, the number of which is correlated with age [51,52].

Focusing on the analysis of EAOC, it was reported that EAOC and nearby endometriosis were the same clone [53]. Notably, the endometriosis of the Douglas pouch, probably caused by reflux from the uterus, also had the same clone as the EAOC. This result suggested a relationship between EAOC and eutopic endometrium.

The relationship between endometrial cancer, especially endometrioid carcinoma, and endometriosis has also been reported. Epidemiologically, the risk of developing endometrioid carcinoma of the endometrium is as high as 2.1 [54] or 2.8 times [55] in endometriosis cases. Furthermore, in cases of double cancer of the endometrium and ovary, endometriosis significantly coexisted, with 13 out of 13 cases [56] and 21 out of 24 cases [57]. Genomic sequencing of double cancer of the endometrium and ovary revealed they had the same clone in 22 of 23 cases except Lynch syndrome [58]. In another report, 13 out of 14 cases had the same clone [59]. Thus, endometrial cancer, endometriosis, and ovarian cancer may be strongly related to each other in double cancer.

A summary of the genetic alterations commonly found in endometrium, endometriosis, and EAOC is shown in Table 1. All of them are driver genes whose mutations were confirmed by sequencing. Many driver gene mutations are common to endometrium, endometriosis, and EAOC. In addition, when comparing these with endometrial cancer gene mutations from The Cancer Genome Atlas [60], a significant number of them are consistent with endometrium, endometriosis, and EAOC gene mutations. This suggests that EAOC is similar in nature to endometrial cancer arising from the endometrium.

\section{Reconsideration of the Developmental Mechanism of EAOC Based on Molecular and Epidemiological Data}

From the epidemiological and molecular data described above, there are several pieces of evidence that could not be well explained if ECs themselves had become EAOC. Therefore, we now consider the mechanism of EAOC carcinogenesis as follows (Figure 2). Carcinogenesis requires an initiator and a promoter. First, gene mutations occur frequently in endometrial glandular epithelial cells, which enables endometrial cells to survive when they flow back into the abdominal cavity. However, endometriosis is much more common than EAOC because its mutations are often insufficient as initiators for ovarian cancer. Nonetheless, eutopic endometrial glandular epithelial cells with sufficient gene mutations, when engrafted in the ovaries by menstrual blood reflux, cause carcinogenesis through the effect of the cancer-promoting ovarian microenvironment. However, cells with an initiator mutation may not always cause carcinogenesis, which is similar to the fact that inoculating immunodeficient mice with cancer cells does not result in 100\% tumor formation. Therefore, even if the cells are from the same clone as the cancer, if they survive in the contralateral ovary or outside the ovary, they may not cause carcinogenesis, and such cells become endometriosis. Thus, EAOC with endometriosis occurs. In addition, the defect in the ovarian surface caused by ovulation may be particularly rich in growth factors as promoters, and OC prevents EAOC through the suppression of ovulation. The wound after cystectomy of ECs also causes the microenvironment to become rich in growth factors, and EAOC is likely to develop in the ipsilateral ovary after cystectomy.

In ovarian cancer, the prognosis for recurrence in the preserved ovaries after fertility-conserving treatment is good if radical surgery is performed again [61], and all six cases of EAOC (OEC and OCCC) have been reported to be cured [62]. That is, these recurrences may not be the result of hematogenous metastasis or intra-abdominal dissemination, but rather, the tumor cells may remain in the genital tract and be transported from the endometrium to the ovaries.

Our hypothesis can be naturally inferred from epidemiological and underlying data. However, no data to directly prove this has been reported. Although many of the gene mutations in the glands of endometriosis tissue were also found in normal eutopic endometrium by exome sequencing [49], 
the study did not look for mutations at each gland. Endometrial glands are known to be monoclonal $[53,63]$; therefore, to prove that endometriosis or EAOC is caused by the regurgitation of endometrial gland ducts with genetic mutations, it is necessary to analyze each gene mutation in the glands and to identify the glands that are the same clones as endometriosis and EAOC. As demonstrated by gene mutation analysis that high-grade serous carcinoma is derived from serous tubal intraepithelial carcinoma (STIC) [64], if precancerous lesions are detected by meticulous sectioning of the endometrium in EAOC, it is considered that the sequencing analysis can prove that EAOC is derived from the endometrium. However, it is considered difficult to select endometrial glands to be sequenced based on histopathology. To prove that eutopic endometrium with genetic mutations causes endometriosis and EAOC, it is necessary to further advance the sequencing technology in addition to meticulous sectioning of the endometrium.

In addition, the question remains as to why clear cell carcinoma rarely occurs in the endometrium. Normal endometrial glandular epithelium includes estrogen receptor (ER)-positive secretory cells and ER-negative ciliated cells. Recently, it was proposed that each of them is highly likely to be the origin of OEC and OCCC, respectively [65]. Since there are few ER-negative ciliated cells in the eutopic endometrium, the proliferation of ciliated cells might be suppressed in the endometrial environment through interactions with stromal cells. The reason that clear cell carcinoma is more common in the ovary but less so in the endometrium might be because the mechanism that suppresses ciliated cell proliferation does not work in the ovarian microenvironment but rather is advantageous for ciliated cell proliferation. This hypothesis needs to be verified by basic research in the future.

Regarding endometriosis and ovarian mesenchymal tumors, it has been reported that endometrioid stromal sarcoma and adenosarcoma are associated with endometriosis. They are both extremely rare tumors. In a case series of 63 cases of endometrioid stromal sarcoma, 27 cases had ovarian involvement, and 16 of the 27 cases also had endometriosis [66]. However, detailed histopathology of the endometriosis and tumors in each case was not presented and a genomic analysis was not performed. As for adenosarcoma, it often results from extraovarian endometriosis [67], but only a few cases have been reported that suggested an association with ECs [68]. Thus, the pathogenetic mechanism of ovarian mesenchymal tumor development is unclear, and further study is required.
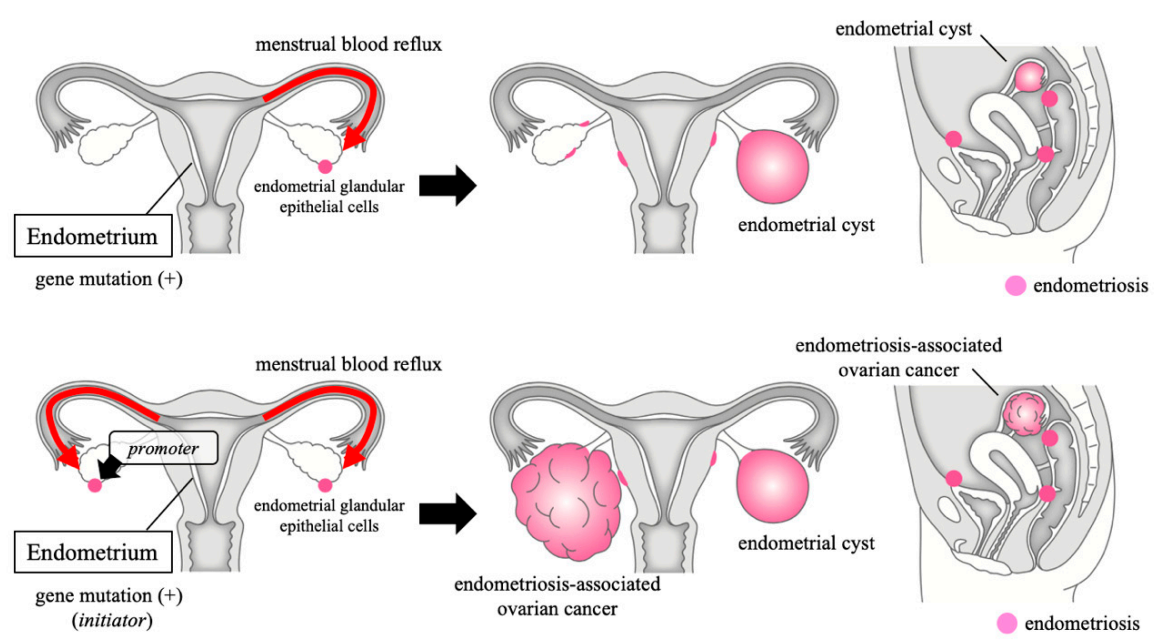

Figure 2. Mechanism of endometriosis-associated ovarian cancer carcinogenesis. Carcinogenesis requires an initiator and a promoter. Gene mutations occur frequently in endometrial glandular epithelial cells, but its mutations are often insufficient as initiators. Nonetheless, endometrial glandular epithelial cells with sufficient gene mutations cause carcinogenesis through the effect of the promoter. If they survive in the contralateral ovary or outside the ovary, they may not cause carcinogenesis, and such cells become endometriosis. This figure was made by modifying a figure from Clinical Gynecology and Obstetrics 2020 [69]. 


\section{The Pros and Cons of Managing Endometriosis with Ovarian Cancer Development in Mind}

The World Endometriosis Society stated that the relative and absolute risk of ovarian cancer in women with endometriosis is very low and routine screening for ovarian cancer was not recommended [70]. The ESHRE guidelines also recommended not to manage endometriosis for carcinogenesis [7]. ECs cause infertility, dysmenorrhea, and abdominal pain due to infection or rupture. Furthermore, differentiation from ovarian cancer is difficult in some cases. Therefore, surgery is required after all in many individuals. However, in ECs, there is no evidence for screening to detect cancer at early stage, or for surgery aimed solely at preventing carcinogenesis.

If it is not necessary to consider fertility preservation when performing surgery for symptoms or other gynecological disorders, the risk of ovarian cancer associated with endometriosis may be reduced by tubal ligation, salpingectomy, and hysterectomy. Considering the prevention of high-grade serous ovarian carcinoma, which is known to originate from the fallopian tubes, salpingectomy might be better than tubal ligation [71]. OCs reduce the risk of ovarian cancer. However, it does not mean that OCs prevent the "malignant transformation of ECs". If the ECs were actually "cancer from the beginning", it is unlikely that OCs would prevent ovarian cancer. There is no evidence that asymptomatic ECs should be followed up. It might be a good idea to follow up several months or one year after diagnosing "ECs" to identify "cancer from the beginning" by monitoring the size or solid region. However, if the size decreases after menopause, it is unlikely that the cyst is "cancer from the beginning", and the risk of developing ovarian cancer may not be higher, so it is not necessary to monitor. Screening of ovarian cancer has no effect on slow-growing type I ovarian cancer, including EAOC [72]. Ovarian cancer occurs in around $1-2 \%$ of women as long as the ovaries are present, but screening for ovarian cancer is more likely to be harmful to the patient as a result of the unnecessary medical care and thus should be avoided [73].

If we can accurately and noninvasively diagnose whether a tumor is EC or EAOC, we can avoid overdiagnosis and overtreatment resulting from concerns regarding the malignant transformation of ECs. It has been reported that many ovarian cancer cases have gene mutations and chromosome number abnormalities (copy number increases of chromosome $7 \mathrm{q}$ and $8 \mathrm{q}$ ) in cervical Pap smear samples or endometrial Tao brush samples [74]. Even when limited to stage I OCCC or OEC, findings were positive in 10 of 23 cervical Pap smear samples and in two of four endometrial Tao brush samples. This may be because of the detection of genetic mutations in endometrial glandular epithelial cells or cell-free DNA derived from these cells. Therefore, if an ovarian cyst is identified that appears to be an EC, it may be accurately diagnosed as ovarian cancer by examining a sample from the cervix or endometrium for genetic abnormalities. Furthermore, proteomic analysis of endometrial fluid and circulating tumor DNA may be used to detect precursor lesions in EAOCs and to investigate the risk of developing EAOCs [75].

\section{Landscape of Targeted Therapy and Immunotherapy for EAOC}

There is still no standard use of therapies targeting EAOC genetic mutations. However, the development of targeted therapy will play an important role in improving the prognosis of OCCC, especially in chemotherapy-resistant OCCC. In addition, immunotherapy has been shown to be effective as a treatment for EAOC.

In OCCC, PIK3CA mutations are found in $33-40 \%$ of cases [76], activating the PI3K/AKT/mTOR pathway. Many clinical trials have been conducted on inhibitors of this pathway, including PI3K, AKT, and mTORC1 inhibitors [77]. None have yet been used as a standard treatment, but they could be a promising targeted therapy. A study that performed whole exome sequencing in 48 OCCC cases found several patients that may have responded to existing molecular targeted drugs; furthermore, this study demonstrated the utility of OCCC in exome sequencing [78]. Poly (ADP-ribose) polymerase (PARP) inhibitors have been shown to be effective against ovarian cancer, with $B R C A 1 / B R C A 2$ gene mutations resulting in homologous recombination deficiency [79-82]. Although $B R C A 1 / 2$ gene mutations resulting 
in homologous recombination deficiency are found in only 6-8\% of EAOCs [83], PARP inhibitors may be effective in cases with mutations.

The expression of VEGF, an angiogenic factor, is significantly elevated in EAOC compared with endometriosis [84] and is reported to be expressed in more than $90 \%$ of OCCC cases [85]. Anti-VEGF antibodies, which are angiogenesis inhibitors, have already been used for ovarian cancer, including EAOC [86-90]. Although there are no data showing that anti-VEGF antibodies are more likely to be effective in EAOC than other histology types, it is possible that they may be shown to be effective for EAOC in combination with other drugs in the future.

Several clinical trials of immunotherapy for ovarian cancer have also been conducted, mainly with immune checkpoint inhibitors. In our phase 2 clinical trial of the anti-PD-1 antibody, nivolumab, for platinum-resistant ovarian cancer, the overall response was $15 \% ; 2$ of 20 patients had a complete response, one of which was pathologically OCCC [91]. In addition, a subgroup analysis of a phase 2 clinical trial of the anti-PD-1 antibody, pembrolizumab, for advanced and recurrent ovarian cancer (Keynote 100) showed an objective response rate to OCCC of $16 \%$, which was higher than other histopathological types [92]. The results of these trials suggested that OCCC, among other EAOCs, is more likely to respond to immunotherapy. A phase 2 study of nivolumab \pm ipilimumab for OCCC (NCT03355976) is currently in progress [93]. In addition, in Lynch syndrome, germline mutations are found in MLH1, MSH2, MSH6, and PMS2 and their associated parts among mismatch repair genes, and the cumulative morbidity rate of ovarian cancer is higher (10-12\%) compared with the general population [94]. In a study that performed whole exome sequencing of OCCC, there were $3(6 \%)$ of 48 suspected cases of Lynch syndrome, suggesting that Lynch syndrome may be associated with a certain frequency in OCCC [76], in which mismatch repair gene mutations lead to high frequency microsatellite instability, a susceptibility biomarker for immune checkpoint inhibitors [95]. Therefore, it is more likely that immune checkpoint inhibitors will be effective in OCCC associated with Lynch syndrome.

The IL-6/JAK/STAT pathway is activated in OCCC, and it was reported that IL-6 expression was an independent poor prognostic factor in OCCC [96]. Studies using cell lines have suggested that inhibitors of this pathway are promising for treatment [97]. It was also reported that administration of an anti-IL-6 antibody to an OCCC mouse model improved prognosis [98], indicating the potential for future clinical applications.

ARID1A gene mutations are found in as many as $50 \%$ of OCCC cases $[99,100]$. The activity of histone deacetylase 6 (HDAC6) has been shown to be closely associated with ovarian cancer with ARID1A mutations [101], and the efficacy of HDAC6 inhibitors and combination therapy with anti-PD-L1 antibodies has been demonstrated in an OCCC mouse model lacking the ARID1A gene [102], which may also have future clinical applications. 
Table 1. Previous report of gene alteration in endometrium, endometriosis, endometriosis-associated ovarian cancer, and endometrial carcinoma.

\begin{tabular}{|c|c|c|c|c|c|c|}
\hline \multirow[t]{2}{*}{ Gene } & \multirow[t]{2}{*}{ Function } & \multicolumn{4}{|c|}{ Specimen } & \multirow{2}{*}{$\begin{array}{c}\text { TCGA } \\
\text { Endometrial } \\
\text { Carcinoma }[60]\end{array}$} \\
\hline & & $\begin{array}{l}\text { Endometrium } \\
{[48,51,52,103]}\end{array}$ & $\begin{array}{l}\text { Endometriosis } \\
{[47,48,103-105]}\end{array}$ & $\begin{array}{c}\text { OCCC } \\
{[76,78,99,100,103,106-114]}\end{array}$ & $\begin{array}{c}\text { OEC } \\
{[100,103,110]}\end{array}$ & \\
\hline PIKЗСА & $\begin{array}{l}\text { PI3K/Akt/mTOR } \\
\text { pathway }\end{array}$ & - & $\bullet$ & $\bullet$ & - & $\bullet$ \\
\hline PTEN & $\begin{array}{l}\text { PI3K/Akt/mTOR } \\
\text { pathway }\end{array}$ & $\bullet$ & $\bullet$ & $\bullet$ & $\bullet$ & - \\
\hline$E R B B 2$ & $\begin{array}{l}\mathrm{PI} 3 \mathrm{~K} / \mathrm{Akt} / \mathrm{mTOR} \\
\text { pathway }\end{array}$ & - & - & - & & - \\
\hline PIK3R1 & $\begin{array}{l}\text { PI3K/Akt/mTOR } \\
\text { pathway }\end{array}$ & - & & - & $\bullet$ & - \\
\hline KRAS & $\begin{array}{l}\text { Ras/MAPK } \\
\text { pathway }\end{array}$ & $\bullet$ & - & - & - & - \\
\hline NF1 & $\begin{array}{l}\text { Ras/MAPK } \\
\text { pathway }\end{array}$ & • & & - & - & \\
\hline ARID1A & SWI/SNF complex & & - & - & - & - \\
\hline PPP2R1A & $\begin{array}{l}\text { Serine/threonine-protein } \\
\text { phosphatase }\end{array}$ & - & $\bullet$ & - & & - \\
\hline MLH1 & $\begin{array}{l}\text { Mismatch repair } \\
\text { protein }\end{array}$ & $\bullet$ & $\bullet$ & $\bullet$ & & $\bullet$ \\
\hline CTNNB1 & $\begin{array}{c}\text { Wnt } / \beta \text {-catenin } \\
\text { signaling pathway }\end{array}$ & & $\bullet$ & $\bullet$ & & - \\
\hline KMT2D & $\begin{array}{c}\text { Histone } \\
\text { methyltransferase }\end{array}$ & $\bullet$ & & - & & \\
\hline FBXW7 & Ubiquitin ligase & - & & & - & - \\
\hline
\end{tabular}

\section{Conclusions}

In recent years, basic and epidemiological data suggesting that genetic mutations in the eutopic endometrium may be responsible for EAOC have been accumulating. EAOC might not occur as a result of malignant transformation of glandular epithelial cells of low-risk ECs that will gradually accrue gene mutations over a long period but might be caused by eutopic endometrial glandular epithelial cells with sufficient oncogenic mutations that are refluxed to engraft in the ovary. That is, "ECs" in which EAOC occurs during follow-up is considered to be "cancer from the beginning". There is no evidence that ovarian cancer arises from ECs, and management with "malignant transformation of ECs" in mind might not be recommended. Within EAOC, especially for chemotherapy-resistant OCCC, it is necessary to conduct research and develop targeted therapy, keeping in mind that endometrial glandular epithelial cells serve as a carcinogenic site.

Author Contributions: K.M. and N.M. conceptualized the study and wrote the manuscript. Y.K. and H.N. contributed to collection of reference articles. All authors have reviewed this manuscript and read and approved the final version of it. All authors have read and agreed to the published version of the manuscript.

Funding: This research received no external funding.

Conflicts of Interest: The authors declare no conflict of interest.

\section{References}

1. Giudice, L.C. Clinical practice. Endometriosis. N. Engl. J. Med. 2010, 362, 2389-2398. [CrossRef]

2. Anglesio, M.S.; Yong, P.J. Endometriosis-associated ovarian cancers. Clin. Obstet. Gynecol. 2017, 60, 711-727. [CrossRef] [PubMed]

3. Wang, C.; Liang, Z.; Liu, X.; Zhang, Q.; Li, S. The association between endometriosis, tubal ligation, hysterectomy and epithelial ovarian cancer: Meta-analyses. Int. J. Environ. Res. Public Health 2016, 13, 1138. [CrossRef] [PubMed]

4. Vercellini, P.; Vigano, P.; Somigliana, E.; Fedele, L. Endometriosis: Pathogenesis and treatment. Nat. Rev. Endocrinol. 2014, 10, 261-275. [CrossRef] [PubMed]

5. Mostoufizadeh, M.; Scully, R.E. Malignant tumors arising in endometriosis. Clin. Obstet. Gynecol. 1980, 23, 951-963. [CrossRef] 
6. Nagase, S.; Ohta, T.; Takahashi, F.; Enomoto, T. The 2017 Committee on Gynecologic Oncology of the Japan Society of Obstetrics and Gynecology. Annual report of the Committee on Gynecologic Oncology, the Japan Society of Obstetrics and Gynecology: Annual patients report for 2015 and annual treatment report for 2010. J. Obstet. Gynaecol. Res. 2019, 45, 289-298.

7. Dunselman, G.A.; Vermeulen, N.; Becker, C.; Calhaz-Jorge, C.; D’Hooghe, T.; De Bie, B.; Heikinheimo, O.; Horne, A.W.; Kiesel, L.; Nap, A.; et al. ESHRE guideline: Management of women with endometriosis. Hum. Reprod. 2014, 29, 400-412. [CrossRef]

8. Kawaguchi, R.; Matsumoto, K.; Akira, S.; Ishitani, K.; Iwasaku, K.; Ueda, Y.; Okagaki, R.; Okano, H.; Oki, T.; Koga, K.; et al. Guidelines for office gynecology in Japan: Japan Society of Obstetrics and Gynecology (JSOG) and Japan Association of Obstetricians and Gynecologists (JAOG) 2017 edition. J. Obstet. Gynaecol. Res. 2019, 45, 766-786. [CrossRef]

9. Parazzini, F.; Esposito, G.; Tozzi, L.; Noli, S.; Bianchi, S. Epidemiology of endometriosis and its comorbidities. Eur. J. Obstet. Gynecol. Reprod. Biol. 2017, 209, 3-7. [CrossRef]

10. Shafrir, A.L.; Farland, L.V.; Shah, D.K.; Harris, H.R.; Kvaskoff, M.; Zondervan, K.; Missmer, S.A. Risk for and consequences of endometriosis: A critical epidemiologic review. Best Pract. Res. Clin. Obstet. Gynaecol. 2018, 51, 1-15. [CrossRef]

11. Taylor, H.S.; Giudice, L.C.; Lessey, B.A.; Abrao, M.S.; Kotarski, J.; Archer, D.F.; Diamond, M.P.; Surrey, E.; Johnson, N.P.; Watts, N.B.; et al. Treatment of Endometriosis-Associated Pain with Elagolix, an Oral GnRH Antagonist. N. Engl. J. Med. 2017, 377, 28-40. [CrossRef] [PubMed]

12. Zondervan, K.T.; Becker, C.M.; Missmer, S.A. Endometriosis. N. Engl. J. Med. 2020, 382, 1244-1256. [CrossRef] [PubMed]

13. Carvalho, L.F.; Samadder, A.N.; Agarwal, A.; Fernandes, L.F.; Abrão, M.S. Oxidative stress biomarkers in patients with endometriosis: Systematic review. Arch. Gynecol. Obstet. 2012, 286, 1033-1040. [CrossRef] [PubMed]

14. Scutiero, G.; Iannone, P.; Bernardi, G.; Bonaccorsi, G.; Spadaro, S.; Volta, C.A.; Greco, P.; Nappi, L. Oxidative stress and endometriosis: A systematic review of the literature. Oxid. Med. Cell Longev. 2017, 2017, 7265238. [CrossRef]

15. Yamaguchi, K.; Mandai, M.; Toyokuni, S.; Hamanishi, J.; Higuchi, T.; Takakura, K.; Fujii, S. Contents of endometriotic cysts, especially the high concentration of free iron, are a possible cause of carcinogenesis in the cysts through the iron-induced persistent oxidative stress. Clin. Cancer Res. 2008, 14, 32-40. [CrossRef] [PubMed]

16. Kehrer, J.P. The Haber-Weiss reaction and mechanisms of toxicity. Toxicology 2000, 149, 43-50. [CrossRef]

17. Ito, F.; Yamada, Y.; Shigemitsu, A.; Akinishi, M.; Kaniwa, H.; Miyake, R.; Yamanaka, S.; Kobayashi, H. Role of oxidative stress in epigenetic modification in endometriosis. Reprod. Sci. 2017, 24, 1493-1502. [CrossRef]

18. Kobayashi, H. Potential scenarios leading to ovarian cancer arising from endometriosis. Redox Rep. 2016, 21, 119-126. [CrossRef]

19. Marí-Alexandre, J.; Carcelén, A.P.; Agababyan, C.; Moreno-Manuel, A.; García-Oms, J.; Calabuig-Fariñas, S.; Gilabert-Estellés, J. Interplay between microRNAs and oxidative stress in ovarian conditions with a focus on ovarian cancer and endometriosis. Int. J. Mol. Sci. 2019, 20, 5322. [CrossRef]

20. Melin, A.; Sparén, P.; Persson, I.; Bergqvist, A. Endometriosis and the risk of cancer with special emphasis on ovarian cancer. Hum. Reprod. 2006, 21, 1237-1242. [CrossRef]

21. Aris, A. Endometriosis-associated ovarian cancer: A ten-year cohort study of women living in the Estrie Region of Quebec, Canada. J. Ovarian Res. 2010, 3, 2. [CrossRef] [PubMed]

22. Olson, J.E.; Cerhan, J.R.; Janney, C.A.; Anderson, K.E.; Vachon, C.M.; Sellers, T.A. Postmenopausal cancer risk after self-reported endometriosis diagnosis in the Iowa Women's Health Study. Cancer 2002, 94, 1612-1618. [CrossRef] [PubMed]

23. Kobayashi, H.; Sumimoto, K.; Moniwa, N.; Imai, M.; Takakura, K.; Kuromaki, T.; Morioka, E.; Arisawa, K.; Terao, T. Risk of developing ovarian cancer among women with ovarian endometrioma: A cohort study in Shizuoka, Japan. Int. J. Gynecol. Cancer 2007, 17, 37-43. [CrossRef] [PubMed]

24. Murakami, K.; Kotani, Y.; Shiro, R.; Takaya, H.; Nakai, H.; Matsumura, N. Endometriosis-associated ovarian cancer occurs early during follow-up of endometrial cysts. Int. J. Clin. Oncol. 2020, 25, 51-58. [CrossRef]

25. Friberg, S.; Mattson, S. On the growth rates of human malignant tumors: Implications for medical decision making. J. Surg. Oncol. 1997, 65, 284-297. [CrossRef] 
26. Kuo, H.H.; Huang, C.Y.; Ueng, S.H.; Huang, K.G.; Lee, C.L.; Yen, C.F. Unexpected epithelial ovarian cancers arising from presumed endometrioma: A 10-year retrospective analysis. Taiwan J. Obstet. Gynecol. 2017, 56, 55-61. [CrossRef]

27. Wang, K.C.; Chang, W.H.; Lee, W.L.; Huang, N.; Huang, H.Y.; Yen, M.S.; Guo, C.Y.; Wang, P.H. An increased risk of epithelial ovarian cancer in Taiwanese women with a new surgico-pathological diagnosis of endometriosis. BMC Cancer 2014, 14, 831. [CrossRef]

28. Pearce, C.L.; Templeman, C.; Rossing, M.A.; Lee, A.; Near, A.M.; Webb, P.M.; Nagle, C.M.; Doherty, J.A.; Cushing-Haugen, K.L.; Wicklund, K.G.; et al. Association between endometriosis and risk of histological subtypes of ovarian cancer: A pooled analysis of case-control studies. Lancet Oncol. 2012, 13, 385-394. [CrossRef]

29. Shappell, H.W.; Riopel, M.A.; Smith, A.E.; Ronnett, B.M.; Kurman, R.J. Diagnostic criteria and behavior of ovarian seromucinous (endocervical-type mucinous and mixed cell-type) tumors: Atypical proliferative (borderline) tumors, intraepithelial, microinvasive, and invasive carcinomas. Am. J. Surg. Pathol. 2002, 26, 1529-1541. [CrossRef]

30. Wentzensen, N.; Poole, E.M.; Trabert, B.; White, E.; Arslan, A.A.; Patel, A.V.; Setiawan, V.W.; Visvanathan, K.; Weiderpass, E.; Adami, H.O.; et al. Ovarian cancer risk factors by histologic subtype: An analysis from the Ovarian Cancer Cohort Consortium. J. Clin. Oncol. 2016, 34, 2888-2898. [CrossRef]

31. Kim, H.S.; Kim, T.H.; Chung, H.H.; Song, Y.S. Risk and prognosis of ovarian cancer in women with endometriosis: A meta-analysis. Br. J. Cancer 2014, 110, 1878-1890. [CrossRef] [PubMed]

32. Irving, J.A.; Clement, P.B. Disease of the Peritoneum. In Blaustein's Pathology of the Female Genital Tract, 7th ed.; Kurman, R.J., Ellenson, L.H., Ronnett, B.M., Eds.; Springer: New York, NY, USA, 2019; pp. 799-802.

33. Fukunaga, M.; Nomura, K.; Ishikawa, E.; Ushigome, S. Ovarian atypical endometriosis: Its close association with malignant epithelial tumours. Histopathology 1997, 30, 249-255. [CrossRef] [PubMed]

34. McCluggage, W.G. Endometriosis-related pathology: A discussion of selected uncommon benign, premalignant and malignant lesions. Histopathology 2020, 76, 76-92. [CrossRef]

35. Cibula, D.; Widschwendter, M.; Májek, O.; Dusek, L. Tubal ligation and the risk of ovarian cancer: Review and meta-analysis. Hum. Reprod. Update 2011, 17, 55-67. [CrossRef] [PubMed]

36. Sieh, W.; Salvador, S.; McGuire, V.; Weber, R.P.; Terry, K.L.; Rossing, M.A.; Risch, H.; Wu, A.H.; Webb, P.M.; Moysich, K.; et al. Tubal ligation and risk of ovarian cancer subtypes: A pooled analysis of case-control studies. Int. J. Epidemiol. 2013, 42, 579-589. [CrossRef]

37. Taniguchi, F.; Harada, T.; Kobayashi, H.; Hayashi, K.; Momoeda, M.; Terakawa, N. Clinical characteristics of patients in Japan with ovarian cancer presumably arising from ovarian endometrioma. Gynecol. Obstet. Investig. 2014, 77, 104-110. [CrossRef]

38. Haraguchi, H.; Koga, K.; Takamura, M.; Makabe, T.; Sue, F.; Miyashita, M.; Urata, Y.; Izumi, G.; Harada, M.; Hirata, T.; et al. Development of ovarian cancer after excision of endometrioma. Fertil. Steril. 2016, 106, 1432-1437. [CrossRef] [PubMed]

39. Brinton, L.A.; Sakoda, L.C.; Sherman, M.E.; Frederiksen, K.; Kjaer, S.K.; Graubard, B.I.; Olsen, J.H.; Mellemkjaer, L. Relationship of benign gynecologic diseases to subsequent risk of ovarian and uterine tumors. Cancer Epidemiol. Biomark. Prev. 2005, 14, 2929-2935. [CrossRef]

40. Saraswat, L.; Ayansina, D.; Cooper, K.G.; Bhattacharya, S.; Horne, A.W. Impact of endometriosis on risk of further gynaecological surgery and cancer: A national cohort study. BJOG 2018, 125, 64-72. [CrossRef]

41. Dixon-Suen, S.C.; Webb, P.M.; Wilson, L.F.; Tuesley, K.; Stewart, L.M.; Jordan, S.J. The association between hysterectomy and ovarian cancer risk: A population-based record-linkage study. J. Natl. Cancer Inst. 2019, 111, 1097-1103. [CrossRef]

42. Modugno, F.; Ness, R.B.; Allen, G.O.; Schildkraut, J.M.; Davis, F.G.; Goodman, M.T. Oral contraceptive use, reproductive history, and risk of epithelial ovarian cancer in women with and without endometriosis. Am. J. Obstet. Gynecol. 2004, 191, 733-740. [CrossRef]

43. Ayhan, A.; Mao, T.L.; Seckin, T.; Wu, C.H.; Guan, B.; Ogawa, H.; Futagami, M.; Mizukami, H.; Yokoyama, Y.; Kurman, R.J.; et al. Loss of ARID1A expression is an early molecular event in tumor progression from ovarian endometriotic cyst to clear cell and endometrioid carcinoma. Int. J. Gynecol. Cancer 2012, 22, 1310-1315. [CrossRef] [PubMed] 
44. Matsumoto, T.; Yamazaki, M.; Takahashi, H.; Kajita, S.; Suzuki, E.; Tsuruta, T.; Saegusa, M. Distinct $\beta$-catenin and PIK3CA mutation profiles in endometriosis-associated ovarian endometrioid and clear cell carcinomas. Am. J. Clin. Pathol. 2015, 144, 452-463. [CrossRef]

45. Sato, N.; Tsunoda, H.; Nishida, M.; Morishita, Y.; Takimoto, Y.; Kubo, T.; Noguchi, M. Loss of heterozygosity on 10q23.3 and mutation of the tumor suppressor gene PTEN in benign endometrial cyst of the ovary: Possible sequence progression from benign endometrial cyst to endometrioid carcinoma and clear cell carcinoma of the ovary. Cancer Res. 2000, 60, 7052-7056. [PubMed]

46. Akahane, T.; Sekizawa, A.; Purwosunu, Y.; Nagatsuka, M.; Okai, T. The role of p53 mutation in the carcinomas arising from endometriosis. Int. J. Gynecol. Pathol. 2007, 26, 345-351. [CrossRef]

47. Anglesio, M.S.; Papadopoulos, N.; Ayhan, A.; Nazeran, T.M.; Noë, M.; Horlings, H.M.; Lum, A.; Jones, S.; Senz, J.; Seckin, T.; et al. Cancer-associated mutations in endometriosis without cancer. N. Engl. J. Med. 2017, 376, 1835-1848. [CrossRef] [PubMed]

48. Suda, K.; Nakaoka, H.; Yoshihara, K.; Ishiguro, T.; Tamura, R.; Mori, Y.; Yamawaki, K.; Adachi, S.; Takahashi, T.; Kase, H.; et al. Clonal expansion and diversification of cancer-associated mutations in endometriosis and normal endometrium. Cell Rep. 2018, 24, 1777-1789. [CrossRef]

49. Li, X.; Zhang, Y.; Zhao, L.; Wang, L.; Wu, Z.; Mei, Q.; Nie, J.; Li, Y.; Fu, X.; Wang, X.; et al. Whole-exome sequencing of endometriosis identifies frequent alterations in genes involved in cell adhesion and chromatin-remodeling complexes. Hum. Mol. Genet. 2014, 23, 6008-6021. [CrossRef]

50. Wilson, M.R.; Holladay, J.; Chandler, R.L. A mouse model of endometriosis mimicking the natural spread of invasive endometrium. Hum. Reprod. 2020, 35, 58-69. [CrossRef]

51. Lac, V.; Nazeran, T.M.; Tessier-Cloutier, B.; Aguirre-Hernandez, R.; Albert, A.; Lum, A.; Khattra, J.; Praetorius, T.; Mason, M.; Chiu, D.; et al. Oncogenic mutations in histologically normal endometrium: The new normal? J. Pathol. 2019, 249, 173-181. [CrossRef]

52. Moore, L.; Leongamornlert, D.; Coorens, T.H.H.; Sanders, M.A.; Ellis, P.; Dentro, S.C.; Dawson, K.J.; Butler, T.; Rahbari, R.; Mitchell, T.J.; et al. The mutational landscape of normal human endometrial epithelium. Nature 2020, 580, 640-646. [CrossRef] [PubMed]

53. Anglesio, M.S.; Bashashati, A.; Wang, Y.K.; Senz, J.; Ha, G.; Yang, W.; Aniba, M.R.; Prentice, L.M.; Farahani, H.; Li, C.H.; et al. Multifocal endometriotic lesions associated with cancer are clonal and carry a high mutation burden. J. Pathol. 2015, 236, 201-209. [CrossRef] [PubMed]

54. Mogensen, J.B.; Kjær, S.K.; Mellemkjær, L.; Jensen, A. Endometriosis and risks for ovarian, endometrial and breast cancers: A nationwide cohort study. Gynecol. Oncol. 2016, 143, 87-92. [CrossRef] [PubMed]

55. Yu, H.C.; Lin, C.Y.; Chang, W.C.; Shen, B.J.; Chang, W.P.; Chuang, C.M. Increased association between endometriosis and endometrial cancer: A nationwide population-based retrospective cohort study. Int. J. Gynecol. Cancer 2015, 25, 447-452. [CrossRef] [PubMed]

56. Yamanoi, K.; Mandai, M.; Suzuki, A.; Matsumura, N.; Baba, T.; Yoshioka, Y.; Kosaka, K.; Konishi, I. Synchronous primary corpus and ovarian cancer: High incidence of endometriosis and thrombosis. Oncol. Lett. 2012, 4, 375-380. [CrossRef] [PubMed]

57. Kobayashi, Y.; Nakamura, K.; Nomura, H.; Banno, K.; Irie, H.; Adachi, M.; Iida, M.; Umene, K.; Nogami, Y.; Masuda, K.; et al. Clinicopathologic analysis with immunohistochemistry for DNA mismatch repair protein expression in synchronous primary endometrial and ovarian cancers. Int. J. Gynecol. Cancer 2015, 25, 440-446. [CrossRef]

58. Schultheis, A.M.; Ng, C.K.; De Filippo, M.R.; Piscuoglio, S.; Macedo, G.S.; Gatius, S.; Perez, M.B.; Soslow, R.A.; Lim, R.S.; Viale, A.; et al. Massively parallel sequencing-based clonality analysis of synchronous endometrioid endometrial and ovarian carcinomas. J. Natl. Cancer Inst. 2016, 108, djv427. [CrossRef]

59. Chao, A.; Wu, R.C.; Jung, S.M.; Lee, Y.S.; Chen, S.J.; Lu, Y.L.; Tsai, C.L.; Lin, C.Y.; Tang, Y.H.; Chen, M.Y.; et al. Implication of genomic characterization in synchronous endometrial and ovarian cancers of endometrioid histology. Gynecol. Oncol. 2016, 143, 60-67. [CrossRef]

60. Kandoth, C.; Schultz, N.; Cherniack, A.D.; Akbani, R.; Liu, Y.; Shen, H.; Robertson, A.G.; Pashtan, I.; Shen, R.; Benz, C.C.; et al. Integrated genomic characterization of endometrial carcinoma. Nature 2013, 497, 67-73.

61. Mandelbaum, R.S.; Klar, M.; Takiuchi, T.; Bainvoll, L.; Matsuzaki, S.; Paulson, R.J.; Matsuo, K. Fertility-sparing treatment for early-stage epithelial ovarian cancer: Contemporary oncologic, reproductive and endocrinologic perspectives. J. Obstet. Gynaecol. Res. 2020. [CrossRef] 
62. Bentivegna, E.; Fruscio, R.; Roussin, S.; Ceppi, L.; Satoh, T.; Kajiyama, H.; Uzan, C.; Colombo, N.; Gouy, S.; Morice, P. Long-term follow-up of patients with an isolated ovarian recurrence after conservative treatment of epithelial ovarian cancer: Review of the results of an international multicenter study comprising 545 patients. Fertil. Steril. 2015, 104, 1319-1324. [CrossRef]

63. Tanaka, M.; Kyo, S.; Kanaya, T.; Yatabe, N.; Nakamura, M.; Maida, Y.; Okabe, M.; Inoue, M. Evidence of the monoclonal composition of human endometrial epithelial glands and mosaic pattern of clonal distribution in luminal epithelium. Am. J. Pathol. 2003, 163, 295-301. [CrossRef]

64. Eckert, M.A.; Pan, S.; Hernandez, K.M.; Loth, R.M.; Andrade, J.; Volchenboum, S.L.; Faber, P.; Montag, A.; Lastra, R.; Peter, M.E.; et al. Genomics of Ovarian Cancer Progression Reveals Diverse Metastatic Trajectories Including Intraepithelial Metastasis to the Fallopian Tube. Cancer Discov. 2016, 6, 1342-1351. [CrossRef] [PubMed]

65. Cochrane, D.R.; Tessier-Cloutier, B.; Lawrence, K.M.; Nazeran, T.; Karnezis, A.N.; Salamanca, C.; Cheng, A.S.; McAlpine, J.N.; Hoang, L.N.; Gilks, C.B.; et al. Clear cell and endometrioid carcinomas: Are their differences attributable to distinct cells of origin? J. Pathol. 2017, 243, 26-36. [CrossRef] [PubMed]

66. Masand, R.P.; Euscher, E.D.; Deavers, M.T.; Malpica, A. Endometrioid stromal sarcoma: A clinicopathologic study of 63 cases. Am. J. Surg. Pathol. 2013, 37, 1635-1647. [CrossRef]

67. Stern, R.C.; Dash, R.; Bentley, R.C.; Snyder, M.J.; Haney, A.F.; Robboy, S.J. Malignancy in endometriosis: Frequency and comparison of ovarian and extraovarian types. Int. J. Gynecol. Pathol. 2001, 20, 133-139. [CrossRef] [PubMed]

68. Kondi-Pafiti, A.; Spanidou-Carvouni, H.; Papadias, K.; Hatzistamou-Kiari, I.; Kontogianni, K.; Liapis, A.; Smyrniotis, V. Malignant neoplasms arising in endometriosis: Clinicopathological study of 14 cases. Clin. Exp. Obstet. Gynecol. 2004, 31, 302-304. [PubMed]

69. Matsumura, N.; Murakami, K. Limitations and points of conservative treatment: Carcinogenesis and early diagnosis of endometrial cysts (in Japanese). Clin. Gynecol. Obstet. 2020, in press.

70. Johnson, N.P.; Hummelshoj, L.; World Endometriosis Society Montpellier Consortium. Consensus on current management of endometriosis. Hum. Reprod. 2013, 28, 1552-1568. [CrossRef]

71. ACOG Committee Opinion No. 774. Opportunistic salpingectomy as a strategy for epithelial ovarian cancer prevention. Obstet. Gynecol. 2019, 133, e279-e284.

72. Temkin, S.M.; Miller, E.A.; Samimi, G.; Berg, C.D.; Pinsky, P.; Minasian, L. Outcomes from ovarian cancer screening in the PLCO trial: Histologic heterogeneity impacts detection, overdiagnosis and survival. Eur. J. Cancer 2017, 87, 182-188. [CrossRef] [PubMed]

73. Grossman, D.C.; Curry, S.J.; Owens, D.K.; Barry, M.J.; Davidson, K.W.; Doubeni, C.A.; Epling, J.W.; Kemper, A.R.; Krist, A.H.; Kurth, A.E.; et al. Screening for ovarian cancer: US Preventive Services Task Force Recommendation statement. JAMA 2018, 319, 588-594. [PubMed]

74. Wang, Y.; Li, L.; Douville, C.; Cohen, J.D.; Yen, T.T.; Kinde, I.; Sundfelt, K.; Kjær, S.K.; Hruban, R.H.; Shih, I.M.; et al. Evaluation of liquid from the Papanicolaou test and other liquid biopsies for the detection of endometrial and ovarian cancers. Sci. Transl. Med. 2018, 10, eaap8793. [CrossRef] [PubMed]

75. Dawson, A.; Fernandez, M.L.; Anglesio, M.; Yong, P.J.; Carey, M.S. Endometriosis and endometriosis-associated cancers: New insights into the molecular mechanisms of ovarian cancer development. Ecancermedicalscience 2018, 12, 803. [CrossRef] [PubMed]

76. Kuo, K.T.; Mao, T.L.; Jones, S.; Veras, E.; Ayhan, A.; Wang, T.L.; Glas, R.; Slamon, D.; Velculescu, V.E.; Kuman, R.J.; et al. Frequent activating mutations of PIK3CA in ovarian clear cell carcinoma. Am. J. Pathol. 2009, 174, 1597-1601. [CrossRef]

77. Mabuchi, S.; Sugiyama, T.; Kimura, T. Clear cell carcinoma of the ovary: Molecular insights and future therapeutic perspectives. J. Gynecol. Oncol. 2016, 27, e31. [CrossRef]

78. Shibuya, Y.; Tokunaga, H.; Saito, S.; Shimokawa, K.; Katsuoka, F.; Bin, L.; Kojima, K.; Nagasaki, M.; Yamamoto, M.; Yaegashi, N.; et al. Identification of somatic genetic alterations in ovarian clear cell carcinoma with next generation sequencing. Genes Chromosomes Cancer 2018, 57, 51-60. [CrossRef]

79. Pujade-Lauraine, E.; Ledermann, J.A.; Selle, F.; Gebski, V.; Penson, R.T.; Oza, A.M.; Korach, J.; Huzarski, T.; Poveda, A.; Pignata, S.; et al. Olaparib tablets as maintenance therapy in patients with platinum-sensitive, relapsed ovarian cancer and a BRCA1/2 mutation (SOLO2/ENGOT-Ov21): A double-blind, randomised, placebo-controlled, phase 3 trial. Lancet Oncol. 2017, 18, 1274-1284. [CrossRef] 
80. Moore, K.; Colombo, N.; Scambia, G.; Kim, B.G.; Oaknin, A.; Friedlander, M.; Lisyanskaya, A.; Floquet, A.; Leary, A.; Sonke, G.S.; et al. Maintenance olaparib in patients with newly diagnosed advanced ovarian cancer. N. Engl. J. Med. 2018, 379, 2495-2505. [CrossRef]

81. González-Martín, A.; Pothuri, B.; Vergote, I.; DePont Christensen, R.; Graybill, W.; Mirza, M.R.; McCormick, C.; Lorusso, D.; Hoskins, P.; Freyer, G.; et al. Niraparib in patients with newly diagnosed advanced ovarian cancer. N. Engl. J. Med. 2019, 381, 2391-2402. [CrossRef]

82. Ledermann, J.A.; Oza, A.M.; Lorusso, D.; Aghajanian, C.; Oaknin, A.; Dean, A.; Colombo, N.; Weberpals, J.I.; Clamp, A.R.; Scambia, G.; et al. Rucaparib for patients with platinum-sensitive, recurrent ovarian carcinoma (ARIEL3): Post-progression outcomes and updated safety results from a randomised, placebo-controlled, phase 3 trial. Lancet Oncol. 2020, 21, 710-722. [CrossRef]

83. Alsop, K.; Fereday, S.; Meldrum, C.; de Fazio, A.; Emmanuel, C.; George, J.; Dobrovic, A.; Birrer, M.J.; Webb, P.M.; Stewart, C.; et al. BRCA mutation frequency and patterns of treatment response in BRCA mutation-positive women with ovarian cancer: A report from the Australian Ovarian Cancer Study Group. J. Clin. Oncol. 2012, 30, 2654-2663. [CrossRef]

84. Barreta, A.; Sarian, L.O.; Ferracini, A.C.; Costa, L.B.E.; Mazzola, P.G.; de Angelo Andrade, L.; Derchain, S. Immunohistochemistry expression of targeted therapies biomarkers in ovarian clear cell and endometrioid carcinomas (type I) and endometriosis. Hum. Pathol. 2019, 85, 72-81. [CrossRef]

85. Mabuchi, S.; Kawase, C.; Altomare, D.A.; Morishige, K.; Hayashi, M.; Sawada, K.; Ito, K.; Terai, Y.; Nishio, Y.; Klein-Szanto, A.J.; et al. Vascular endothelial growth factor is a promising therapeutic target for the treatment of clear cell carcinoma of the ovary. Mol. Cancer Ther. 2010, 9, 2411-2422. [CrossRef] [PubMed]

86. Burger, R.A.; Brady, M.F.; Bookman, M.A.; Fleming, G.F.; Monk, B.J.; Huang, H.; Mannel, R.S.; Homesley, H.D.; Fowler, J.; Greer, B.E.; et al. Incorporation of bevacizumab in the primary treatment of ovarian cancer. N. Engl. J. Med. 2011, 365, 2473-2483. [CrossRef]

87. Perren, T.J.; Swart, A.M.; Pfisterer, J.; Ledermann, J.A.; Pujade-Lauraine, E.; Kristensen, G.; Carey, M.S.; Beale, P.; Cervantes, A.; Kurzeder, C.; et al. A phase 3 trial of bevacizumab in ovarian cancer. N. Engl. J. Med. 2011, 365, 2484-2496. [CrossRef] [PubMed]

88. Aghajanian, C.; Blank, S.V.; Goff, B.A.; Judson, P.L.; Teneriello, M.G.; Husain, A.; Sovak, M.A.; Yi, J.; Nycum, L.R. OCEANS: A randomized, double-blind, placebo-controlled phase III trial of chemotherapy with or without bevacizumab in patients with platinum-sensitive recurrent epithelial ovarian, primary peritoneal, or fallopian tube cancer. J. Clin. Oncol. 2012, 30, 2039-2045. [CrossRef] [PubMed]

89. Pujade-Lauraine, E.; Hilpert, F.; Weber, B.; Reuss, A.; Poveda, A.; Kristensen, G.; Sorio, R.; Vergote, I.; Witteveen, P.; Bamias, A.; et al. Bevacizumab combined with chemotherapy for platinum-resistant recurrent ovarian cancer: The AURELIA open-label randomized phase III trial. J. Clin. Oncol. 2014, 32, 1302-1308. [CrossRef]

90. Coleman, R.L.; Brady, M.F.; Herzog, T.J.; Sabbatini, P.; Armstrong, D.K.; Walker, J.L.; Kim, B.G.; Fujiwara, K.; Tewari, K.S.; O'Malley, D.M.; et al. Bevacizumab and paclitaxel-carboplatin chemotherapy and secondary cytoreduction in recurrent, platinum-sensitive ovarian cancer (NRG Oncology/Gynecologic Oncology Group study GOG-0213): A multicentre, open-label, randomised, phase 3 trial. Lancet Oncol. 2017, 18, 779-791. [CrossRef]

91. Hamanishi, J.; Mandai, M.; Ikeda, T.; Minami, M.; Kawaguchi, A.; Murayama, T.; Kanai, M.; Mori, Y.; Matsumoto, S.; Chikuma, S.; et al. Safety and Antitumor Activity of Anti-PD-1 Antibody, Nivolumab, in Patients With Platinum-Resistant Ovarian Cancer. J. Clin. Oncol. 2015, 33, 4015-4022. [CrossRef]

92. Matulonis, U.A.; Shapira-Frommer, R.; Santin, A.D.; Lisyanskaya, A.S.; Pignata, S.; Vergote, I.; Raspagliesi, F.; Sonke, G.S.; Birrer, M.; Provencher, D.M.; et al. Antitumor activity and safety of pembrolizumab in patients with advanced recurrent ovarian cancer: Results from the phase II KEYNOTE-100 study. Ann. Oncol. 2019, 30, 1080-1087. [CrossRef] [PubMed]

93. NIH U.S. National Library of Medicine ClinicalTrials.gov. Available online: https://clinicaltrials.gov/ct2/home (accessed on 13 June 2020).

94. Schmeler, K.M.; Lynch, H.T.; Chen, L.M.; Munsell, M.F.; Soliman, P.T.; Clark, M.B.; Daniels, M.S.; White, K.G.; Boyd-Rogers, S.G.; Conrad, P.G.; et al. Prophylactic surgery to reduce the risk of gynecologic cancers in the Lynch syndrome. N. Engl. J. Med. 2006, 354, 261-269. [CrossRef] [PubMed] 
95. Latham, A.; Srinivasan, P.; Kemel, Y.; Shia, J.; Bandlamudi, C.; Mandelker, D.; Middha, S.; Hechtman, J.; Zehir, A.; Dubard-Gault, M.; et al. Microsatellite Instability Is Associated With the Presence of Lynch Syndrome Pan-Cancer. J. Clin. Oncol. 2019, 37, 286-295. [CrossRef] [PubMed]

96. Kawabata, A.; Yanaihara, N.; Nagata, C.; Saito, M.; Noguchi, D.; Takenaka, M.; Iida, Y.; Takano, H.; Yamada, K.; Iwamoto, M.; et al. Prognostic impact of interleukin-6 expression in stage I ovarian clear cell carcinoma. Gynecol. Oncol. 2017, 146, 609-614. [CrossRef]

97. Yanaihara, N.; Hirata, Y.; Yamaguchi, N.; Noguchi, Y.; Saito, M.; Nagata, C.; Takakura, S.; Yamada, K.; Okamoto, A. Antitumor effects of interleukin-6 (IL-6)/interleukin-6 receptor (IL-6R) signaling pathway inhibition in clear cell carcinoma of the ovary. Mol. Carcinog. 2016, 55, 832-841. [CrossRef]

98. Chandler, R.L.; Damrauer, J.S.; Raab, J.R.; Schisler, J.C.; Wilkerson, M.D.; Didion, J.P.; Starmer, J.; Serber, D.; Yee, D.; Xiong, J.; et al. Coexistent ARID1A-PIK3CA mutations promote ovarian clear-cell tumorigenesis through pro-tumorigenic inflammatory cytokine signalling. Nat. Commun. 2015, 6, 6118. [CrossRef]

99. Jones, S.; Wang, T.L.; Shih, I.M.; Mao, T.L.; Nakayama, K.; Roden, R.; Glas, R.; Slamon, D.; Diaz, L.A.; Vogelstein, B.; et al. Frequent mutations of chromatin remodeling gene ARID1A in ovarian clear cell carcinoma. Science 2010, 330, 228-231. [CrossRef]

100. Wiegand, K.C.; Shah, S.P.; Al-Agha, O.M.; Zhao, Y.; Tse, K.; Zeng, T.; Senz, J.; McConechy, M.K.; Anglesio, M.S.; Kalloger, S.E.; et al. ARID1A mutations in endometriosis-associated ovarian carcinomas. N. Engl. J. Med. 2010, 363, 1532-1543. [CrossRef]

101. Bitler, B.G.; Wu, S.; Park, P.H.; Hai, Y.; Aird, K.M.; Wang, Y.; Zhai, Y.; Kossenkov, A.V.; Vara-Ailor, A.; Rauscher, F.J.; et al. ARID1A-mutated ovarian cancers depend on HDAC6 activity. Nat. Cell Biol. 2017, 19, 962-973. [CrossRef]

102. Fukumoto, T.; Fatkhutdinov, N.; Zundell, J.A.; Tcyganov, E.N.; Nacarelli, T.; Karakashev, S.; Wu, S.; Liu, Q.; Gabrilovich, D.I.; Zhang, R. HDAC6 Inhibition Synergizes with Anti-PD-L1 Therapy in ARID1A-Inactivated Ovarian Cancer. Cancer Res. 2019, 79, 5482-5489. [CrossRef]

103. Er, T.K.; Su, Y.F.; Wu, C.C.; Chen, C.C.; Wang, J.; Hsieh, T.H.; Herreros-Villanueva, M.; Chen, W.T.; Chen, Y.T.; Liu, T.C.; et al. Targeted next-generation sequencing for molecular diagnosis of endometriosis-associated ovarian cancer. J. Mol. Med. 2016, 94, 835-847. [CrossRef] [PubMed]

104. Zou, Y.; Zhou, J.Y.; Guo, J.B.; Wang, L.Q.; Luo, Y.; Zhang, Z.Y.; Liu, F.Y.; Tan, J.; Wang, F.; Huang, O.P. The presence of KRAS, PPP2R1A and ARID1A mutations in 101 Chinese samples with ovarian endometriosis. Mutat. Res. 2018, 809, 1-5. [CrossRef] [PubMed]

105. Lac, V.; Verhoef, L.; Aguirre-Hernandez, R.; Nazeran, T.M.; Tessier-Cloutier, B.; Praetorius, T.; Orr, N.L.; Noga, H.; Lum, A.; Khattra, J.; et al. Iatrogenic endometriosis harbors somatic cancer-driver mutations. Hum. Reprod. 2019, 34, 69-78. [CrossRef] [PubMed]

106. Zannoni, G.F.; Improta, G.; Pettinato, A.; Brunelli, C.; Troncone, G.; Scambia, G.; Fraggetta, F. Molecular status of PI3KCA, KRAS and BRAF in ovarian clear cell carcinoma: An analysis of 63 patients. J. Clin. Pathol. 2016, 69, 1088-1092. [CrossRef] [PubMed]

107. Itamochi, H.; Oishi, T.; Oumi, N.; Takeuchi, S.; Yoshihara, K.; Mikami, M.; Yaegashi, N.; Terao, Y.; Takehara, K.; Ushijima, K.; et al. Whole-genome sequencing revealed novel prognostic biomarkers and promising targets for therapy of ovarian clear cell carcinoma. Br. J. Cancer 2017, 117, 717-724. [CrossRef] [PubMed]

108. Murakami, R.; Matsumura, N.; Brown, J.B.; Higasa, K.; Tsutsumi, T.; Kamada, M.; Abou-Taleb, H.; Hosoe, Y.; Kitamura, S.; Yamaguchi, K.; et al. Exome Sequencing Landscape Analysis in Ovarian Clear Cell Carcinoma Shed Light on Key Chromosomal Regions and Mutation Gene Networks. Am. J. Pathol. 2017, 187, 2246-2258. [CrossRef]

109. Maru, Y.; Tanaka, N.; Ohira, M.; Itami, M.; Hippo, Y.; Nagase, H. Identification of novel mutations in Japanese ovarian clear cell carcinoma patients using optimized targeted NGS for clinical diagnosis. Gynecol. Oncol. 2017, 144, 377-383. [CrossRef]

110. Ishikawa, M.; Nakayama, K.; Nakamura, K.; Ono, R.; Sanuki, K.; Yamashita, H.; Ishibashi, T.; Minamoto, T.; Iida, K.; Razia, S.; et al. Affinity-purified DNA-based mutation profiles of endometriosis-related ovarian neoplasms in Japanese patients. Oncotarget 2018, 9, 14754-14763. [CrossRef]

111. Kim, S.I.; Lee, J.W.; Lee, M.; Kim, H.S.; Chung, H.H.; Kim, J.W.; Park, N.H.; Song, Y.S.; Seo, J.S. Genomic landscape of ovarian clear cell carcinoma via whole exome sequencing. Gynecol. Oncol. 2018, 148, 375-382. [CrossRef] 
112. Kato, N.; Sato, Y.; Kamataki, A.; Fukase, M.; Uchigasaki, S.; Kurose, A. PIK3CA hotspot mutations and cyclooxygenase-2 expression in ovarian clear cell carcinomas: A close association with stromal features. Hum. Pathol. 2019, 86, 32-37. [CrossRef]

113. Su, Y.F.; Tsai, E.M.; Chen, C.C.; Wu, C.C.; Er, T.K. Targeted sequencing of a specific gene panel detects a high frequency of ARID1A and PIK3CA mutations in ovarian clear cell carcinoma. Clin. Chim. Acta 2019, 494, 1-7. [CrossRef] [PubMed]

114. Nagasawa, S.; Ikeda, K.; Horie-Inoue, K.; Sato, S.; Takeda, S.; Hasegawa, K.; Inoue, S. Identification of novel mutations of ovarian cancer-related genes from RNA-sequencing data for Japanese epithelial ovarian cancer patients. Endocr. J. 2020, 67, 219-229. [CrossRef] [PubMed]

(C) 2020 by the authors. Licensee MDPI, Basel, Switzerland. This article is an open access article distributed under the terms and conditions of the Creative Commons Attribution (CC BY) license (http://creativecommons.org/licenses/by/4.0/). 